\title{
OLAHRAGA DI BULAN RAMADHAN
}

Oleh: Yuldik Prasetyo

Dosen Jurusan Pendidikan Kesehatan dan Rekreasi FIK UNY

\section{Abstrak}

Puasa adalah menahan diri dari makan, minum dan hubungan seksual serta sesuatu yang membatalkannya sejak dari terbit fajar sampai terbenam matahari dengan niat mendekatkan diri kepada Allah SWT. Olahraga yang dilakukan pada saat berpuasa bertujuan untuk pemeliharaan tubuh agar tetap sehat dan bugar.

Olahraga saat puasa dapat dilakukan dengan intensitas $40 \%$ hingga $50 \%$ lebih sedikit dari zona latihan yang biasa dilakukan. Cukup olah raga ringan seperti senam ringan, jalan dan jogging selama $20 \mathrm{~s} / \mathrm{d} 30$ menit. Waktu pelaksanaan olahraga: 1) saat menjelang buka puasa, 2) usai salat tarawih 3) menjelang sahur. Latihan seperti, yoga, pilates, body balance, lebih tepat dilakukan saat berpuasa. Selain intensitas rendah, latihan tersebut juga memiliki manfaat bagi pikiran dan jiwa. Menu makan saat sahur harus memenuhi kecukupan gizi, yaitu komposisi karbohidrat, protein, dan lemak harus seimbang, $15 \%$ protein, $20-25 \%$ lemak, dan sisanya karbohidrat.

Kata kunci: olahraga, puasa.

Bulan Ramadhan adalah bulan yang paling dinanti oleh umat muslim. Saat itu dianggap sebagai bulan yang penuh berkah dan rahmah. Menurut Nadjib Sudarmawan (2006: 4) dilihat dari bahasa puasa adalah menahan diri dari sesuatu atau berpantang dari apa saja, sedangkan secara syar'i (agama Islam) puasa adalah menahan 
diri dari makan, minum dan hubungan seksual serta sesuatu yang membatalkannya sejak dari terbit fajar sampai terbenam matahari dengan niat mendekatkan diri kepada Allah SWT. Semua umat muslim yang sehat dan sudah akil baliq diwajibkan untuk berpuasa sebulan penuh. Meskipun untuk sebagian orang ibadah puasa cukup berat, tetapi terdapat keistimewaan untuk mendapatkan hikmah dari Allah berupa kebahagian, pahala berlipat, dan bahkan suatu muhjizat dalam kesehatan. Dengan berpuasa akan bermanfaat secara biopsikososial berupa sehat jasmani, rohani dan sosial. Rahasia muhkizat kesehatan yang dijanjikan dalam berpuasa inilah yang menjadi daya tarik ilmuwan untuk meneliti berbagai aspek kesehatan puasa secara psikobiologis, imunopatofisilogis dan biomolekular.

Olahraga merupakan kebutuhan pokok manusia. Dengan olahraga secara teratur, maka akan meningkatkan kebugaran. Olahraga teratur juga meningkatkan stamina/daya tahan tubuh, rasa percaya diri dan daya ingat yang semakin kuat, mengurangi stress, kemampuan seksual, memperlancar peredaran darah. Selain itu meningkatkan kolateralisasi, yaitu berkembangnya pembuluh darah kecil/mikrosirkulasi di jantung, ginjal, dan organ lainnya, sehingga mengurangi risiko serangan jantung. Meskipun memiliki berbagai keterbatasan selama berpuasa, bukan berarti aktivitas kita hanya diisi dengan tidur atau bermalas-malasan. Agar tetap bugar, olahraga sebaiknya tidak ditinggalkan.

MEDIKORA Vol. V, No 1, April 2009: 92-101 
Prinsip olahraga yang dilakukan pada saat berpuasa adalah pemeliharaan tubuh agar tetap sehat dan bugar. Artinya, harus mampu melancarkan aliran darah dan melenturkan otot-otot, jantung lebih aktif, dan zat asam atau oksigen lebih banyak terhirup sebagai proses metabolisme tubuh (http://kesehatan.kompas.com). Lalu, bagaimana dengan olahraga di bulan Ramadhan? Olahraga selama puasa ramadhan sebaiknya tetap dikerjakan. Sebab, hal ini akan menambah kebugaran, mempertahankan daya tahan tubuh serta manfaat lainnya. Namun waktu pelaksanaan, jenis olahraga, dosis dan waktu olahraga perlu disesuaikan dengan kondisi puasa.

\section{Strategi Olahraga dan Pola Makan Saat Puasa}

Kesehatan merupakan salah satu nikmat Allah SWT yang wajib kita syukuri. Kesehatan merupakan mahkota bagi manusia yang mahal harganya, dengan memilikinya, seseorang dapat melaksanakan ibadah dan amanah yang dipikulkan di atas pundak kita dengan sempurna sebagai hamba Allah dan khalifah-Nya di muka bumi (Muchlas Abror, 1994: 7). Untuk itu, strategi olahraga dan pola makan saat puasa harus dilakukan dengan baik agar derajat kesehatan selalu tetap terpelihara.

Hal yang paling dikhawatirkan dalam olahraga, apabila dilakukan saat puasa adalah menurunnya cadangan cairan tubuh/dehidrasi. Untuk mengganti cairan tubuh, maka harus menunggu saat berbuka. Akibatnya bisa jadi tubuh akan 
kekurangan air. Keadaan ini dapat mengganggu fungsi organ tubuh yang lain. Oleh karena itu, waktu paling tepat untuk berolahraga adalah setengah hingga satu jam sebelum berbuka puasa. Dengan demikian, tak perlu terlalu lama menunggu untuk minum sesuai kebutuhan. Cairan atau keringat yang dikeluarkan tubuh waktu berolahraga dapat segera tergantikan. Segera minum setelah berlatih, juga dapat menurunkan kembali suhu badan yang meningkat akibat panas yang terjadi ketika berolahraga.

Pada saat sore hari sibuk menyiapkan hidangan buka puasa, waktu olahraga dapat diundur setelah berbuka. Tunggu dua jam setelah perut diisi makanan agar organ pencernaan memiliki cukup waktu untuk mencerna. Jika olahraga di malam hari jadi pilihan, perlu diingat tubuh kita pun memerlukan istirahat. Sebaiknya berhenti berolahraga 3 jam sebelum tidur. Sebab tubuh perlu waktu memulihkan diri agar dapat melakukan kegiatan sahur esok harinya (http://jadilangsing.com/exercise/exercise_detail)

Dengan perubahan pola makan, yang perlu kita lakukan adalah menyiasatinya sehingga masih tetap mendukung gaya hidup sehat. Untuk tetap mempertahankan massa otot, gunakan waktu berbuka puasa untuk mengonsumsi karbohidrat dan protein dalam jumlah yang tinggi. Hal itu bertujuan untuk memberi makan otot dan sel-sel tubuh dan menghindari penurunan otot akibat lapar yang berlebihan. Kemudian dilanjutkan berolahraga lebih kurang setelah shalat tarawih setelah latihan masukan protein dan karbohidrat lagi. Pastikan menu makan saat sahur telah memenuhi

MEDIKORA Vol. V, No 1, April 2009: 92-101 
kecukupan gizi. Komposisi karbohidrat, protein, dan lemak juga harus seimbang, yaitu 15\% protein, 20-25\% lemak, dan sisanya karbohidrat. Kekurangan protein dapat menyebabkan banyaknya protein tubuh yang dipecah saat olahraga. Padahal protein ini penting untuk proses metabolisme sel-sel otak dan saraf.

Satu jam setelah latihan konsumsi lagi meal yang lebih kurang sama dengan waktu berbuka puasa. Saat sahur, konsumsilah makanan yang lebih tinggi kadar serat dan lemaknya. $\mathrm{Hal}$ itu untuk menjaga kesehatan dan regularitas pembuangan. Jangan lupa juga untuk mengonsumsi protein solid, seperti daging, ayam, dan ikan. Gunakan waktu lebih kurang 30 menit sebelum berbuka puasa untuk melakukan latihan aerobik ringan, seperti berjalan di treadmill atau bersepeda dengan kondisi hipoglikemi sehingga tubuh kita dengan mudah sekali memanfaatkan sel-sel lemak untuk sumber energi. Segera sesudahnya berbukalah terlebih dulu dengan minuman yang manis. Menurut riset ilmiah, minuman dingin lebih mudah diserap tubuh daripada minuman hangat. Kemudian konsumsikan meal berprotein tinggi dengan komposisi karbohidrat yang tidak terlalu banyak (Yudan R, 2005, Suara Merdeka).

\section{Metode Olahraga di Bulan Ramadhan}

Keseimbangan adalah kata kunci dari ajaran Islam. Keseimbangan tersebut meliputi kebutuhan jasmani dan rohani. Dimana olahraga diperlukan untuk memperkuat badan, dan 
kebersihàn rohani untuk mengontrol sekaligus mengarahkan jasmani untuk melakukan aktivitas yang baik juga benar. Jika berat salah satunya dikhawatirkan keseimbangan terganggu. Menurut Mathmud (2000: 61-62) bahwa antara hati, jiwa, akal, dan ruh pengertiannya saling berkorelasi, saling bergantian tempat, dan memiliki kemiripan satu sama lain dalam berbagai hal. Sedangkan orang yang tidak mengetahui interelasi dan kemiripan antara keempat hal tadi sering kali terperosok kedalam kesalahan. Untuk itu, agar tidak terjadi kesalahan olahraga di bulan ramadhan, maka seseorang harus mengetahui metode yang akan digunakannya.

Saat puasa, penentuan intensitas dalam berolahraga sangat penting. Menurut Djoko P.I (2000: 14) intensitas adalah kualitas yang menunjukkan berat-ringannya latihan. Olahraga di bulan ramadhan dapat dilakukan dengan intensitas 40\% hingga 50\% lebih sedikit dari zona latihan yang biasa dilakukan. Contoh: apabila biasa lari lima kali seminggu selama satu jam, maka saat puasa cukup lakukan jalan cepat tiga kali seminggu, masingmasing 30 menit. Setiap berolahraga di bulan ramadhan juga jangan lupa melakukan pemanasan dan pendinginan. Lakukan gerakan-gerakan peregangan (stretching), dengan tujuan dapat terhindar dari cedera atau nyeri otot setelah melakukan olahraga (http://jadilangsing.com/exercise/exercise_detail).

Seorang yang sedang berpuasa apabila memungkinkan dapat melakukan sedikit olahraga di rumah dengan beban tubuh sendiri (latihan kalistenik). Hal itu untuk merangsang otot agar

MEDIKORA Vol. V, No 1, April 2009: 92-101 
tetap digunakan. Penggunaan otot secara sederhana ini bisa membantu mencegah de-training yang sangat cepat menyebabkan katabolik.

Púasa memberi kesempatan kepada alat-alat pencernaan untuk beristirahat 'setelah bekerja keras sepanjang tahun. Lambung dan usus beristirahat selama beberapa jam dari kegiatannya, sekaligus memberi kesempatan untuk menyembuhkan infeksi dan luka yang ada sehingga dapat menutup rapat. Proses penyerapan makanan juga berhenti sehingga asam amoniak, glukosa dan garam tidak masuk ke usus. Dengan demikian sel-sel usus tidak mampu lagi membuat komposisi glikogen, protein dan kolesterol. Disamping dari segi makanan, dari segi gerak (olah raga), dalam bulan puasa banyak sekali gerakan yang dilakukan terutama lewat pergi ibadah (http://www.scribd.com/doc).

Olahraga selama puasa jangan dilakukan terlalu berat. Sebab akan menguras tenaga, kekurangan cairan atau dehidrasi, apalagi jika tinggal daerah iklim panas. Cukup olah raga ringan seperti senam ringan, jalan dan jogging selama $20 \mathrm{~s} / \mathrm{d} 30$ menit. Waktu pelaksanaan olahraga: 1) Saat menjelang buka puasa, jika haus atau lemas karena kurangnya kadar gula dalam darah hanya berlangsung beberapa saat saja. Waktu berbuka dapat segera diatasi dengan minum minuman manis. Berbeda jika olahraga yang dilakukan pagi atau siang hari. Jika terjadi haus atau lemas tentu akan menimbulkan masalah, karena waktu berbuka puasa masih 
lama. 2) Usai salat tarawih 3) Menjelang sahur. Apabila olahraga menjelang berbuka puasa tentu harus menyesuaikan dengan kondisi tubuh. Jika rasa lemas dan haus cukup mengganggu, ini merupakan bahasa tubuh atau gejala kita kekurangan cairan dan gula darah. Maka sebaiknya olahraga tidak dilakukan (http://www.jantungku.com/2008/09/).

Untuk olahraga lain, bisa menggunakan sepeda, spinning atau jalan pakai treadmil. Olahraga seperti jalan sehat atau jalan cepat juga bisa menjadi pilihan. Olahraga kardio tersebut justru dianjurkan sebelum berbuka puasa. Latihan pembakaran yang berfungsi untuk kardiovaskular tersebut bermanfaat saat perut kosong. Satu atau setengah jam sebelum berbuka, latihan kardio bisa membakar lemak untuk, dipergunakan sebagai energi. Menurut personal trainer profesional Jefry Sihite, latihan seperti, yoga, pilates, body balance, lebih tepat dilakukan saat berpuasa. Selain intensitas rendah, latihan tersebut juga memiliki manfaat bagi pikiran dan jiwa (http://rumahdiabetes.com/2007).

\section{KESIMPULAN}

Olahraga yang dilakukan pada saat berpuasa mempunyai tujuan pemeliharaan tubuh agar tetap sehat dan bugar. Artinya, harus mampu melancarkan aliran darah dan melenturkan otototot, jantung lebih aktif, dan zat asam atau oksigen lebih banyak terhirup sebagai proses metabolisme tubuh. Olahraga saat puasa dapat dilakukan dengan intensitas 40\% hingga 50\% lebih sedikit

MEDIKORA Vol. V, No 1, April 2009: 92-101 
dari zona latihan yang biasa dilakukan. Cukup olah raga ringan seperti senam ringan, jalan dan jogging selama $20 \mathrm{~s} / \mathrm{d} 30$ menit. Waktu pelaksanaan olahraga: 1) saat menjelang buka puasa, 2) usai salat tarawih 3) menjelang sahur. Latihan seperti, yoga, pilates, body balance, lebih tepat dilakukan saat berpuasa. Selain intensitas rendah, latihan tersebut juga memiliki manfaat bagi pikiran dan jiwa.

\section{Daftar Pustaka}

Djoko P.I (2000). Panduan Latihan Kebugaran (Yang Efektif dan Aman). Yogyakarta: Lukman Offset.

Mahmud, Ali A.H. (2000). Pendidikan Ruhani. Jakarta: Gema Insani Press.

Muchlas Abror. (1994). Kebersihan, Kesehatan, dan Keindahan. Yogyakarta: Proyek Penerangan Bimbingan dan Dakwah Agama Islam DIY.

Nadjib Sudarmawan. (2006). Tuntunan Ibadah di Bulan Ramadhan. Yogyakarta: Forum Komunikasi Lembaga Dakwah DIY.

Olahraga Sebelum Bedug. Diakses dari http://jadilangsing.com/exercise/exercise_detail.asp?id=51 4, tanggal 13 Maret 2009.

Pentingnya Olahraga Menurut Agama Islam. Diakses dari http://www.scribd.com/doc/17020165/Penelitian-OlahRaga, tanggal 12 Maret 2009. 
Puasa Bukan Alasan Tak Olahraga Diakses dari http: / / kesehatan.kompas.com/read/xml/2009/08/26/14 263273/Puasa.Bukan.Alasan.Tak.Olahraga, tanggal 9 Maret 2009.

Puasa Bukan Berarti Berhenti Olahraga. Diakses dari http://rumahdiabetes.com/2007/09/puasa-bukan-berartiberhenti-olahraga/\# respond, tanggal 12 Maret 2009.

Tetap Berolahraga Selama Puasa. Diakses dari http://www.jantungku.com/2008/09/, tanggal 13 Maret

Yudan R. (2005). Gaya Hidup Fitness di Bulan Puasa. Edisi Minggu, Suara Merdeka, Minggu, 9 Oktober 2005. 